Original article

\title{
Soru Sorma Becerileri Bakımından Türkçe Öğretmeni Adaylarının Hazırladıkları Metni Anlama Sorularının Day ve Park Taksonomisi'ne Göre Değerlendirilmesi
}

\author{
Evaluation of Text Comprehension Questions Prepared by Turkish \\ Teacher Candidates in Terms of Questioning Skills According to Day and \\ Park Taxonomy
}

\author{
Bora Bayram (우 * \\ Department of Turkish and Social Sciences Education, Faculty of Education, Alanya Alaaddin Keykubat University, Alanya, Turkey
}

\begin{abstract}
Özet
Türkçe derslerinde metnin anlaşılabilirliği açısından soru sorma büyük önem taşımaktadır. Çünkü okuma öncesinde, sırasında ve sonrasında yöneltilecek sorularla düşünme harekete geçirilerek öğrenci öğrenmeye sevk edilir. Ancak soru sormak kadar, soruların niteliğine de dikkat edilmelidir. Bu araştırmada Türkçe Öğretmenliği bölümünde öğrenim görmekte olan birinci ve dördüncü sınıf öğretmen adaylarının metne dayalı olarak hazırladığı anlama sorularını değerlendirmek amaçlanmıştır. Nitel araştırmaya uygun şekilde gerçekleştirilen bu çalışma, verilerinin doküman incelemesiyle değerlendirildiği betimsel bir nitelik göstermektedir. Çalışmanın örneklemi belirlenirken kolay ulaşılabilir durum örneklemi kullanılmıştır. Öğretmen adaylarının hazırlamış olduğu sorular, Day ve Park Taksonomisi'nin “basit anlama, yeniden organize etme, çıkarım yapma, tahmin, değerlendirme ve kişisel tepki” şeklindeki basamaklarına göre değerlendirilmiştir. Araştırma sonuçlarına göre hem 1. sınıf hem de 4. sınıf öğretmen adaylarının hazırladıkları metni anlama soruları ağırlıkıı olarak basit anlama düzeyindedir. (1. sınıf \% 36, 4. sınıf \% 31) Her iki sınıfta da bunu sırasıyla tahmin etme (1. sınıf \% 17, 4. sınıf \% 23) ve çıkarım yapma (1. sınıf \% 16, 4. sınıf \% 19) düzeyi sorular izlemektedir. Soruların ağırlıkları her iki grupta da aynı basamaklarda yoğunlaşsa da oranlar aynı değildir. Bu bulgular, çıkarım yapma ve değerlendirme gibi üstbilişsel zihinsel becerileri gerektirecek sorular sorma açısından son sınıf öğrencileri lehine bir görünüm arz etmektedir. Tercih edilen metin türü açısından 1. sınıf öğrencilerinin öyküleyici, 4. sınıf öğrencilerinse bilgilendirici metinleri daha çok tercih ettiklerini görmekteyiz. Buna göre birincil düzeyde soru sorabilme becerisi üzerine öğretmen adaylarını düşünmeye sevk ettiğimiz bu çalışmada, her iki sınıfta da adaylar tarafından hazırlanan soruların daha çok anlamı doğrudan metinden çıkarılabilecek sorulardan oluştuğu, Day ve Park Taksonomisi'nin değerlendirme ve yeniden organize etme gibi basamaklarında adayların eksikliklerinin olduğu tespit edilmiştir. Bundan dolayı öğretmen adaylarının mesleki derslere yönelik uygulamalardaki eksikliklerinin telafi edilerek sonraki dönemlerde de bunların göz önünde bulundurulması, soru sorma becerileri açısından farklı taksonomilerin dikkate alınarak adaylara bu yönde bilgi ve tecrübe edindirilmesi önerilmektedir.
\end{abstract}

Anahtar Kelimeler: Türkçe öğretimi, Day ve Park Taksonomisi, soru sorma becerisi.

Abstract

\footnotetext{
* Corresponding author:

Bora Bayram, Department of Turkish and Social Sciences Education, Faculty of Education, Alanya Alaaddin Keykubat University, Alanya, Turkey Email: bora.bayram@alanya.edu.tr
} 
In Turkish lessons, it is of great importance to ask questions in terms of the understandability of the text. Because with the questions to be asked before, during and after the reading, thinking is encouraged and the student is directed to the learning. However, as well as asking questions, attention should be paid to the quality of the questions. In this research, it is aimed to evaluate the comprehension questions based on the text prepared by the first and fourth grade teacher candidates studying in the Turkish Teaching department. This study, which was carried out in accordance with qualitative research, shows a descriptive quality in which its data is evaluated by document review. Probabilistic sampling was used when determining the sample of the study. The questions prepared by the teacher candidates were evaluated according to the steps of the Day and Park taxonomy as "simple comprehension, reorganization, inference, prediction, evaluation and personal response". According to the results of the research, the text comprehension questions prepared by both 1st grade and 4th grade teacher candidates are predominantly at the level of simple comprehension. (1st grade $36 \%$, 4th grade $31 \%$ ) In both grades, this is followed by predicting (1st grade $17 \%$, 4 th grade $23 \%$ ) and inferencing (1st grade $16 \%$, 4th grade $19 \%$ ) questions, respectively. Although the difficulty of the questions is concentrated on the same steps in both groups, the ratios are not the same. These findings seem in favor of senior students in terms of asking questions that require metacognitive mental skills such as making inferences and evaluating. In terms of the preferred type of text, it is seen that 1st grade students prefer storyteller and 4th graders prefer informative texts more. Accordingly, in this study, in which we directed teacher candidates to think about the ability to ask questions at the primary level, it was determined that the questions prepared by the candidates in both classes consisted of questions that could be inferred directly from the text, and that the candidates had shortcomings in the steps such as evaluation and reorganization of the Day and Park Taxonomy. Therefore, it is recommended that the shortcomings of the teacher candidates in the applications for vocational courses be compensated and these should be taken into consideration in the following periods and that the candidates should gain knowledge and experience in this direction by taking into account different taxonomies in terms of questioning skills.

Keywords: Turkish teaching, Day and Park Taxonomy, Questioning Skills.

Received: 16 January $2021 \quad * \quad$ Accepted: 23 January $2021 \quad * \quad$ DOI: https://doi.org/10.29329/jsve.2020.298.4

\section{GİRiş}

Türkçe derslerinde metnin anlaşılabilirliği açısından soru sorma büyük önem taşımaktadır. Çünkü okuma öncesinde, sırasında ve sonrasında yöneltilecek sorularla düşünme harekete geçirilerek öğrenci öğrenmeye sevk edilir. Ancak soru sormak kadar, soruların niteliğine de dikkat edilmelidir. Sadece hatırlamaya yönelik, bilgi düzeyinde, cevabı doğrudan metinden çıkarılan sorular değil, öğrencinin sorgulamasına, eleştirmesine de olanak tanıyan bilişsel süreçleri işletebileceği nitelikteki farklı tip soru örnekleriyle de karşılaşması gerekir. Bu noktada öğretmenlere büyük görevler düşmektedir. Her şeyden önce dersin yürütücüsü öğretmenler, soru sorma becerilerine sahip olmalıdır. İlgili literatür incelendiğinde bu konunun hassasiyeti daha iyi görülmektedir. 5. Sınıf Türkçe ders kitaplarında yer alan metni anlama sorularına yönelik yaptığı çözümleme sonucuna göre Akyol (2001), metin sorularının önemli bir kısmının düşünmeyi gerektirecek sorulara oranla ezbere yönelik cevaplar içerdiğini tespit etmiştir. Benzer şekilde Ülger (2003) yazılı sınavlarda Türkçe öğretmenlerinin sormuş oldukları soruların büyük oranda bilgi, kavrama ve uygulama düzeyinde olduğu sonucuna ulaşmıştır. Karakuş’a 
(2002) göre metin altı soruların üç husus gözetilerek hazırlanması gerekmektedir: Öğrenci soruların cevabını değiştirmeden, olduğu gibi metinden alınması, cevabı metinde bulunan soruların öğrenci tarafından kendi cümleleriyle ifade edilmesi, öğrencinin cevaba kendi yorumunu da katması.

Öğrenme ortamlarında kullanılan bir yöntem olarak soru sorma, bir değerlendirme şekli olarak da öne çıkmaktadır. Bu bağlamda öğrenciler, öğretmenler tarafından iki şekilde değerlendirilmektedir. Birincisi öğretim sürecinin içerisinde uygulamaların şekillendirilmesi ve etkinlikleri çeşitlendirmek üzere yapılan süreç değerlendirme; ikincisi hedeflere ne derece ulaşıldığının, yapılan çalışmaların veriminin çıtılar üzerinden değerlendirilmesine dönük olarak sonuç değerlendirmedir. Süreç içerisinde öğretmenlerin sordukları sorular; sürecin doğru şekilde planlanıp yürütülmesi, öğrencilerin soru sormasına olanak tanıyarak aktif katılımını sağlaması dolayısıyla kalıcı öğrenmenin gerçekleştirilmesi için büyük bir öneme sahiptir (Göçer, 2016). Bu durum öğretmen adaylarının da aynı şekilde nitelikli sorular sorma yönünden eğitilmesi gerektiği gerçeğini doğurmaktadır.

Aslan'a (2011) göre, gerek Türkçe gerekse de Türk dili ve edebiyatı programlarında ölçme/ değerlendirme dersleri aracılığıyla öğretmen adaylarına farklı bilişsel sınıflamalar öğretilerek bunlara yönelik soru hazırlama ve ders işleme eğitimleri verilmelidir. Nitekim öğretmenler, öğrencilerin de soru sorabilen bireyler olarak sürecin bir parçası olması noktasında önemli birer yol gösterici durumundadır (Cooper, 2013). Bundan dolayı öğretmenlerin farklı basamaklardaki soru tiplerini tanıması, bunlara uygun sorular hazırlayabilmesi ve sorularını etkili biçimde sorabilmesi gerekmektedir. Çünkü öğrencilerin gelişimleri, yaratıcı düşünebilmeleri, öğrendiklerini uygulamaya dökebilmeleri, değerlendirme yapabilen ve karar alabilen bireyler olarak var olabilmeleri için bu önem taşımaktadır (Baysen, 2006).

Soru sorma tekniği ve sorulan soruların niteliği, öğrencilere üst düzey düşünme becerileri kazandırmada da önemli bir etkendir. Sadece bilgi düzeyinde sorulan bir soru öğrenciyi hatırlamaya ve ezbere sevk eder. Aksine üst düzey düşünmeyi harekete geçirecek sorularla öğrenciler bilgiyi kullanmaya yöneltilebilir. Erdoğan ve Erdoğan'a (2018) göre başta Türkçe dersi olmak üzere diğer bütün derslerde kullanılan soru-cevap yöntemi ve metne yönelik nitelikli sorular, öğrencilerin düşünmeye sevk edilmesine olanak tanımaktadır.

Öğrenme çıktılarının tespiti ve değerlendirilmesinde, soru sorma becerilerine yönelik olarak hazırlanan taksonomiler alan araştırmacıları ve konunun muhatapları tarafından sıklıkla başvurulan bir kılavuz niteliği taşımaktadır. Bilginin basamakları bakımından sınıflandırılan soruların; konunun ne düzeyde kavrandığı, özümsenerek uygulamaya geçip geçmediğinin tespiti ve bireyin özgün bir ürün ortaya koyma ve yargıda bulunma noktasındaki konumunun belirlenmesi açısından önemi büyüktür (Güfta ve Zorbaz, 2008). 
Tüm dünyada bu bağlamda öne çıkan taksonomiler içerisinde en çok tercih edilen ve pek çok dile çevrilen Bloom'un bilişsel alan taksonomisi (1956) olmuştur. Ülkemizde de yapılan çalışmalar içerisinde daha çok bu taksonominin kullanıldığını görmekteyiz. Ancak okuduğunu anlama becerilerini değerlendirmede kullanılabilecek tek sınıflama bu değildir. Bu sınıflamalardan biri de Day ve Park (2005) tarafından ortaya konan taksonomidir. Bu araştırmada Türkçe eğitiminde yapılan çalışmalarda araştırmacılara fikir sunması açısından, Day ve Park tarafından geliştirilmiş olan taksonomi kullanılmıştır. Söz konusu taksonomiye göre sorular, altı farklı anlama türü açısından sınıflandırılmıştır. Sınıflandırmaya ilişkin gerekli bilgiler Tablo 1'de verilmiştir:

Tablo 1. Day ve Park Taksonomisi

\begin{tabular}{|c|c|c|}
\hline Sinıflama & Açılklama & Soru örnekleri \\
\hline Basit Anlama & $\begin{array}{l}\text { Olgu, yer, zaman, tarih vb. gibi cevabı doğrudan } \\
\text { metinden çıarılabilen soruları kapsar. }\end{array}$ & $\begin{array}{l}\text { Metinde yer alan hayvanlar } \\
\text { nelerdir? }\end{array}$ \\
\hline $\begin{array}{l}\text { Yeniden Organize } \\
\text { Etme }\end{array}$ & $\begin{array}{l}\text { Basit anlamaya dayalı cevapları içermesine rağmen } \\
\text { metnin farklı kısımlarında bulunan bilgileri } \\
\text { kullanmayı, birleştirmeyi gerektirmektedir. }\end{array}$ & $\begin{array}{l}\text { Ayıcık öğretmenine neden } \\
\text { yalan söylemiştir? }\end{array}$ \\
\hline Çıkarım Yapma & $\begin{array}{l}\text { Öğrencinin metinden doğrudan çıkarılabilen cevaplarla } \\
\text { kendi bilgi ve sezgilerini harmanlayarak birlikte } \\
\text { kullanmasını gerektirmektedir. }\end{array}$ & $\begin{array}{l}\text { Aylclğın yalan söylediğini } \\
\text { bildiği halde ögretmen bunu } \\
\text { neden belli etmemiş olabilir? }\end{array}$ \\
\hline Tahmin Etme & $\begin{array}{l}\text { Bu düzey, öğrencilerin metinle ilgili bir fikir sahibi } \\
\text { olmalarının gerektirmektedir. Çünkü okunan bir metin } \\
\text { bittikten sonra veya metnin sonraki bölümünde neler } \\
\text { olabileceğinde dair sistematik tespit gerekmektedir. } \\
\text { Tahmin soruları, okuma sırası ve sonrasında olarak iki } \\
\text { türlü sorulabilir. Okuma sonrası tahmin sorularının } \\
\text { doğru cevabı yoktur. }\end{array}$ & $\begin{array}{l}\text { Ayıcık, ögretmene yalan } \\
\text { söylemeseydi sizce neler } \\
\text { olurdu? }\end{array}$ \\
\hline Değerlendirme & $\begin{array}{l}\text { Öğrencilerin metne yönelik daha kapsamlı yargılarda } \\
\text { bulunmalarını gerektiren bu tür soruların } \\
\text { cevaplanması, metnin konusu yanında farklı konular } \\
\text { hakkında bilgi sahibi olmayı gerektirmektedir. } \\
\text { Öğrencilerin bu tür sorulara cevap vermelerini } \\
\text { kolaylaştırması açısından öğretmenin rol model olması } \\
\text { gerekebilir. }\end{array}$ & $\begin{array}{l}\text { Sizce bu metin yalan söylemek } \\
\text { konusunda bizlere ne gibi } \\
\text { mesajlar veriyor? }\end{array}$ \\
\hline Kişisel Tepki & $\begin{array}{l}\text { Cevaplarının metinde bulunmadığı bu tür sorular, } \\
\text { öğrencilerin metne veya karakterlere yönelik } \\
\text { düşüncelerini ifade etmelerini gerektirmektedir. } \\
\text { Cevaplar metinle ilişkilendirilerek } \\
\text { temellendirilmelidir. }\end{array}$ & $\begin{array}{l}\text { Okuduğunuz metni beğendiniz } \\
\text { mi, neden? }\end{array}$ \\
\hline
\end{tabular}

Day ve Park'tan (2005) uyarlanmıştır.

$\mathrm{Bu}$ araştırmada Türkçe öğretmenliği bölümünde öğrenim görmekte olan birinci ve dördüncü sınıf öğretmen adaylarının metne dayalı olarak hazırlamış oldukları anlama sorularını değerlendirmektir. $\mathrm{Bu}$ kapsamda aşağıdaki sorulara cevap aranmıştır:

2. Türkçe öğretmenliği birinci sınıf öğrencilerinin hazırladıkları metni anlama sorularının Day ve Park Taksonomisi'ne göre dağılımı nasıldır? 
3. Türkçe öğretmenliği dördüncü sınıf öğrencilerinin hazırladıkları metni anlama sorularının Day ve Park Taksonomisi’ne göre dağılımı nasıldır?

4. Türkçe öğretmenliği birinci ve dördüncü sınıf öğrencilerinin hazırladıkları metni anlama sorularının seçilen metin türüne göre dağılımı nasıldır?

\section{YÖNTEM}

\section{Araștırmanın Modeli}

$\mathrm{Bu}$ çalışma, olgu ve olaylar hakkındaki bilgileri içeren yazılı materyallerin analizine yönelik (Yıldırım ve Şimşek, 2015) olarak nitel araştırmaya uygun şekilde gerçekleştirilmiştir. bu çalışma, verilerinin doküman analiziyle değerlendirildiği betimsel bir nitelik göstermektedir. Bu doğrultuda Türkçe öğretmenliği birinci ve dördüncü sınıf öğrencilerinin hazırlamış oldukları metni anlama soruları, doküman inceleme yöntemi kullanılarak Day ve Park Taksonomisi’nin basamaklarına göre incelenerek sinıflandırılmıştır.

\section{Çalışma Grubu}

Araştırmanın çalışma grubu, 2018- 2019 eğitim-öğretim yılının bahar döneminde Bayburt Üniversitesi'nde öğrenim görmekte olan Türkçe Öğretmenliği birinci ve dördüncü sınıf öğrencilerinden oluşmaktadır. Öğrencilerin birinci ve dördüncü sınıftan seçilmesinin sebebi, özel öğretim yöntemleri gibi alan eğitimi derslerini hiç almamış olan ve tamamını almış olan öğretmen adaylarının bu durumlarının soru hazırlama becerilerine yansımalarını tespit etmektir. Çalışmanın örneklemi belirlenirken kolay ulaşılabilir durum örneklemi kullanılmıştır. Bu örneklemin seçilmesindeki temel amaç yakın ve erişilmesinin kolay olmasıdır (Yıldırım ve Şimşek, 2015). Araştırmaya katılan öğretmen adaylarına ilişkin bilgiler Tablo 1'de verilmiştir.

Tablo 2. Araştırmaya Katılan Öğretmen Adayları

\begin{tabular}{lccccc}
\hline & \multicolumn{2}{c}{ Sinıf } & \multicolumn{2}{c}{ 4. sinıf } \\
\hline Cinsiyet & f & f & f & \% \\
\hline Kız & 18 & 60 & 21 & 58 \\
\hline Erkek & 12 & 40 & 15 & 42 \\
\hline Toplam & 30 & 45 & 36 & 55 \\
\hline
\end{tabular}

Tablo 2'ye bakıldığında araştırmaya katılan Türkçe öğretmeni adaylarının 30'u birinci sınıf, 36's1 ise 4. sınıf öğrencilerinden oluşmaktadır. Birinci sınıf öğrencilerinin \%60'ının kı, \%40'ının erkeklerden; dördüncü sınıf öğrencilerinin \%58'inin kız, \%42'sinin ise erkeklerden meydana geldiği görülmektedir. 


\section{Veri Toplama Araçları}

Araştırma kapsamında hem birinci sınıf hem de son sınıf öğrencilerinden ortaokul seviyesine uygun şekilde araştırmacı tarafından oluşturulmuş metin havuzundan bir metin seçmeleri ve seçtikleri metinle ilgili okuma anlamayı değerlendirecek nitelikte en az beş adet soru hazırlamaları istenmiştir. Metin havuzunda yer alan metinler, MEB veya özel yayınevleri tarafından yayınlanmış ve Talim ve Terbiye Kurulu'nun onayından geçmiş Türkçe ders kitaplarındaki metinlerden seçilmiştir.

\section{Verilerin Analizi}

Metne yönelik toplam 367 adet anlama sorusu betimsel analizle incelenmiştir. Öğretmen adaylarının hazırlamış olduğu sorular, Day ve Park Taksonomisi'nin "basit anlama, yeniden organize etme, çıkarım yapma, tahmin, değerlendirme ve kişisel tepki” şeklindeki basamaklarına göre değerlendirilmiştir. Verilerin değerlendirilmesinde alanyazında yer alan çalışmalar gözden geçirilerek her bir basamağa uygun nitelikte örnek sorular hazırlanmıştır. Öğretmen adaylarının hazırladığı sorular, iki ayrı alan uzmanı tarafından ayrı ayrı kodlanarak Miles ve Huberman (1994) güvenirlik formülüne göre \% 84 oranında görüş birliği sağlanmıştır. [görüş birliğii/(görüş ayrıllı̆̆ + görüşş birliği)*100= 83].

\section{BULGULAR}

Tablo 3. Türkçe Öğretmenliği 1. Sınıf Öğrencilerin Hazırladığı Metni anlama Sorularının Day ve Park Taksonomisi’ne Göre Dağılımı

\begin{tabular}{lcccccc}
\hline \multirow{2}{*}{ Day ve Park Taksonomisi } & \multicolumn{2}{c}{ Kuz } & \multicolumn{2}{c}{ Erkek } & \multicolumn{2}{c}{ Toplam } \\
\cline { 2 - 7 } & $\boldsymbol{f}$ & $\mathbf{\%}$ & $\boldsymbol{f}$ & $\mathbf{\%}$ & $\boldsymbol{f}$ & $\boldsymbol{\%}$ \\
\hline Basit anlama & 42 & 35,59 & 22 & 36,67 & 64 & 35,96 \\
\hline Yeniden organize etme & 9 & 7,63 & 12 & 20,00 & 21 & 11,80 \\
\hline Çıkarım yapma & 19 & 16,10 & 10 & 16,67 & 29 & 16,29 \\
\hline Tahmin & 25 & 21,19 & 6 & 10,00 & 31 & 17,42 \\
\hline Değerlendirme & 7 & 5,93 & 4 & 6,67 & 11 & 6,18 \\
\hline Kişisel tepki & 16 & 13,56 & 6 & 10,00 & 22 & 12,36 \\
\hline Toplam & 118 & 66,29 & 60 & 33,71 & 178 & 100 \\
\hline
\end{tabular}

Tablo 3'e göre Türkçe öğretmenliği 1. sınıf öğrencilerinin hazırlamış olduğu toplam soru sayısı 178'dir. Bu soruların \%66,29’u kız, \%33,71'i erkek öğretmen adayları tarafından hazırlanmıştır. Bu oranların ortaya çıkmasında 1. sınıfta öğrenim gören adayların \%60'ının kızlardan meydana gelmesi etken olmuştur. Adayların hazırladığı metni anlama soruları Day ve Park Taksonomisi'ne göre incelendiğinde hem kız hem de erkek öğrenciler açısından aynı sonuçlara ulaşılmıştır. Buna göre her iki grupta yer alan öğretmen adaylarının hazırladığı sorular daha çok basit anlama $(\% 35,96)$ düzeyindedir. Bunu sırasıly tahmin (\%17,42), çıkarım yapma (\%16,29), kişisel tepki $(\% 12,36)$, yeniden organize etme $(\% 11,80)$ izlemektedir. Adayların sormayı en az tercih ettikleri metni anlama sorularınınsa Day ve Park Taksonomisi’nin değerlendirme $(\% 6,18)$ basamağına yönelik olduğu görülmektedir. 
Tablo 4. Türkçe Öğretmenliği 4. Sınıf Öğrencilerinin Hazırladığı Metni Anlama Sorularının Day ve Park Taksonomisi’ne Göre Dağılımı

\begin{tabular}{lcccccc}
\hline \multirow{2}{*}{ Day ve Park Taksonomisi } & \multicolumn{2}{c}{ Kız } & \multicolumn{2}{c}{ Erkek } & \multicolumn{2}{c}{ Toplam } \\
\cline { 2 - 7 } & $\boldsymbol{f}$ & $\boldsymbol{\%}$ & $\boldsymbol{f}$ & $\boldsymbol{\%}$ & $\boldsymbol{f}$ & $\boldsymbol{\%}$ \\
\hline Basit anlama & 40 & 35,40 & 19 & 25,00 & 59 & 31,22 \\
\hline Yeniden organize etme & 8 & 7,08 & 4 & 5,26 & 12 & 6,35 \\
\hline Çıarım yapma & 18 & 15,93 & 18 & 23,68 & 36 & 19,05 \\
\hline Tahmin & 26 & 23,01 & 17 & 22,37 & 43 & 22,75 \\
\hline Değerlendirme & 10 & 8,85 & 6 & 7,89 & 16 & 8,47 \\
\hline Kişisel tepki & 11 & 9,73 & 12 & 15,79 & 23 & 12,17 \\
\hline Toplam & 113 & 59,79 & 76 & 40,21 & 189 & 100 \\
\hline
\end{tabular}

Tablo 4'e göre Türkçe öğretmenliği 4. sınıf öğrencilerinin hazırlamış olduğu toplam soru sayıs1 189'dur. Bu soruların \%59,79’u kız, \%40,21'i erkek öğretmen adayları tarafından hazırlanmıștır. Bu oranların ortaya çıkmasında 1. sınıfta öğrenim gören adayların \%58'inin kızlardan meydana gelmesi etken olmuştur. Adayların hazırladığı metni anlama soruları Day ve Park Taksonomisi'ne göre incelendiğinde hem kız hem de erkek öğrenciler açısından aynı sonuçlara ulaşılmıştır. Buna göre her iki grupta yer alan öğretmen adaylarının hazırladığı sorular daha çok basit anlama $(\% 31,22)$ düzeyindedir. Bunu sırasıyla tahmin(\%22,75), çıkarım yapma (\%19,05) ve kişisel tepki $(\% 12,17)$ izlemektedir. Adayların sormayı en az tercih ettikleri metni anlama sorularınınsa Day ve Park Taksonomisi'nin değerlendirme $(\% 8,47)$ ve yeniden organize etme $(\% 6,35)$ basamağına yönelik olduğu görülmektedir.

Tablo 5. Türkçe Öğretmenliği Birinci ve Dördüncü Sınıf Öğrencilerinin Hazırladıkları Metni Anlama Sorularının Seçilen Metin Türüne Göre Dağılımı

\begin{tabular}{|c|c|c|c|c|c|c|c|c|c|c|c|c|}
\hline \multirow{3}{*}{ Metin türü } & \multicolumn{6}{|c|}{ 1. Sinıf } & \multicolumn{6}{|c|}{ 4. Sinıf } \\
\hline & \multicolumn{2}{|c|}{ Kız } & \multicolumn{2}{|c|}{ Erkek } & \multicolumn{2}{|c|}{ Toplam } & \multicolumn{2}{|c|}{ Kız } & \multicolumn{2}{|c|}{ Erkek } & \multicolumn{2}{|c|}{ Toplam } \\
\hline & $\mathbf{f}$ & $\%$ & f & $\%$ & $\mathbf{f}$ & $\%$ & $\mathbf{f}$ & $\%$ & $\mathbf{f}$ & $\%$ & $\mathbf{f}$ & $\%$ \\
\hline Bilgilendirici & 7 & 38,89 & 5 & 41,67 & 12 & 40 & 8 & 38,10 & 7 & 46,67 & 15 & 41,67 \\
\hline Öyküleyici & 10 & 55,56 & 7 & 58,33 & 17 & 56,67 & 9 & 42,86 & 2 & 13,33 & 11 & 30,56 \\
\hline Şiir & 1 & 5,56 & - & - & 1 & 3,33 & 4 & 19,05 & 6 & 40,00 & 10 & 27,78 \\
\hline Toplam & 18 & 60 & 12 & 40 & 30 & 100 & 21 & 58,33 & 15 & 41,67 & 36 & 100 \\
\hline
\end{tabular}

Tablo 5 incelendiğinde 1. sınıfta öğrenim gören Türkçe öğretmeni adaylarının hazırladıkları toplan soruların \%60’1 kız öğrenciler, \%40’1 erkek öğrenciler tarafından hazırlanmıştır. Öğrencilerin \%56'sı sorularını hazırlarken öyküleyici metin kullanmayı tercih ederken \%40'^ bilgilendirici metinleri, \%3,33'ü ise şiir türü metinleri tercih etmiştir. 4.sınıfta öğrenim gören öğretmen adaylarının hazırladıkları soruların \%58'i kız öğrenciler, \%41'i erkek öğrenciler tarafından hazırlanmıştır. Öğrencilerin \%41,67'si sorularını hazırlarken bilgilendirici metin kullanmayı tercih ederken \%30,56's1 öyküleyici metinleri, \%27,78'i ise şiir türü metinleri tercih etmiştir. Tüm sınıflar dikkate alındığında 
soru hazırlamada en az tercih edilen metinler şiir türü metinler olmuştur. Her iki sınıf seviyesinde de kız öğrencilerin daha çok öyküleyici metinleri tercih ettikleri sonucuna ulaşılmıştır.

\section{Sonuç ve Tartışma}

Araştırma sonuçlarına göre hem 1. sınıf hem de 4. sınıf öğretmen adaylarının hazırladıkları metni anlama sorularının ağırlıklı olarak basit anlama düzeyinde olduğu ortaya konmuştur. Bu sonuçlar, öğretmen adaylarının veya öğretmenlerin bir metne yönelik olarak hazırladıkları soruları veya ders kitaplarındaki metin önü veya metin sonu soruları farklı taksonomiler açısından değerlendiren pek çok çalışmanın sonuçlarıyla benzerlik göstermektedir (Aktaş, 2017; Akyol vd. 2013; Ülper ve Yalınkılıç, 2010; Sarar Kuzu, 2013; Eyüp, 2012; Çeliktürk Sezgin ve Gedikoğlu Özilhan 2019, Durukan, 2009; Güfta ve Zorbaz, 2008; Çeçen ve Kurnaz 2015).

Öğretmen adaylarının farklı metin türlerine yönelik sordukları soruları Bloom Taksonomisi'ne göre değerlendirdiği çalışmasında Aktaş (2017), adayların daha çok hatırlama, anlama ve uygulama gibi alt düzey sorular hazırladıklarını tespit etmiştir. Benzer şekilde Akyol, vd. (2013) yaptığı araştırmanın katılımcıların basit anlama düzeyinde sorular sorma eğiliminde olduğu şekildeki bulguları araştırmamızın sonuçlarıyla benzerlik göstermektedir.

Her iki sınıfta da adaylar tarafından hazırlanan soruların daha çok anlamı doğrudan metinden çıkarılabilecek sorulardan oluştuğu görülmektedir. Bu sonucun ortaya çıkmasının altında öğrencilerin öğrendiklerini ölçme kaygısının yattığını ve soru cevap sürecini bu kaygının yönettiğini söylemek seçeneklerden biridir. Çünkü tüm sınıflarda hazırlanan sorular içerisinde daha çok basit anlama soruları öne çıkmaktadır. Özellikle özel öğretim yöntemleri gibi alan eğitimi derslerini de almış 4. sınıf öğretmen adaylarının dahi ağırlıklı şekilde Day ve Park Taksonomisi'nin basit anlama düzeyinde sorulara yer vermesi bu düşünceyi doğrular niteliktedir. Ancak bununla birlikte soruların ağırlıklarının her iki grupta da aynı basamaklarda yoğunlaşmasına rağmen oranlar aynı değildir. Bu bulgular, çıkarım yapma ve değerlendirme gibi üstbilişsel zihinsel becerileri gerektirecek sorular sorma açısından son sınıf öğrencileri lehine bir görünüm arz etmektedir.

Öğretmen adaylarını birincil düzeyde soru sorabilme becerisi üzerine düşünmeye sevk ettiğimiz bu çalışmada elde edilen sonuçların adayların alt düzey soru sorma eğiliminde olduklarını göstermesi, üzerinde düşünülmesi gereken bir veridir. Bu noktada araştırmaya katılan adayların Day ve Park Taksonomisi’nin özellikle değerlendirme ve yeniden organize etme gibi basamaklarında eksikliklerinin olduğu tespit edilmiştir. Ancak unutulmamalıdır ki öğretmenler, sordukları sorularla öğrencinin bilgisini ölçmek dışında düşünme biçimini de eğitmeye yönelik gizil bir amaç taşımak zorundadırlar. Çünkü bu sayede öğretmenler; analiz, sentez yapma, çözümleme, empati, eleştiri, değerlendirme, yeniden organize etme gibi üst düzey düşünmeyi geliştirecek nitelikteki sorularla öğrencilerin zihinsel gelişimlerine katkı sağlayacaktır. Bundan dolayı öğretmen adaylarının mesleki derslere yönelik 
uygulamalardaki eksikliklerinin telafi edilerek sonraki dönemlerde de bunların göz önünde bulundurulması, soru sorma becerileri açısından farklı taksonomilerin dikkate alınarak adaylara bu yönde bilgi ve tecrübe edindirilmesi önerilmektedir. Nitekim Büyükalan’a (2007) göre bir sinıflama dikkate alınarak düzenlenen sorular, öğretmene yardımcı olmasının yanında öğrencilerin üst düzey düşünme becerilerini geliştirme ve soruların benzer basamaklarda yoğunlaşmasının önüne geçilmesini de sağlayacaktır.

Tercih edilen metin türü açısından 1. sınıf öğrencilerinin öyküleyici, 4. sınıf öğrencilerinse bilgilendirici metinleri daha çok tercih ettiklerini görmekteyiz. Bu durum, birinci sınıf öğrencileri açısından olaya dayalı metinlerden hareketle soru hazırlamanın daha kolay olarak görülmesiyle açıklanabilir. Ancak şiir türü metinlerin metne yönelik anlamaya dayalı soru hazırlamada nispeten tercih edilmemesi, kısa metinler olmalarına rağmen anlamsal yoğunlukları dolayısıyla soru hazırlama açısından elverişli bulunmamasından dolayı olabilir. Kocaarslan ve Yamaç'ın (2018) sınıf öğretmenlerinin Türkçe dersi sınavlarında sordukları sorulara yönelik yaptıkları araştırmanın sonuçlarına göre, sınıf öğretmenleri, sınav sorusu hazırlamada ağırlıklı olarak öyküleyici metinleri kullanmaktadır. Bu sonuç, bu araştırmanın ilgili alt problemine yönelik elde edilen söz konusu bulguyu destekler mahiyettedir. Bu konuda öğretmen adaylarına her çeşit metne yönelik özellikle de Türkçe Dersi Öğretim Programı'nda (2018) sınıf seviyesine göre önerilen metin türlerine yönelik metin önü veya metin sonu sorular hazırlatılmalıdır. Bu konuda öğrencilerin her metinden alacağı şeyler olduğu, her metnin farklı nitelikleriyle farklı kazançlar elde etmek bakımından bir araç olarak kullanılabileceği hissettirilmelidir.

\section{KAYNAKÇA}

Aktaş, E. (2017). Öğretmen adaylarının farklı metin türlerine yönelik soru sorma becerilerinin yenilenmiş Bloom Taksonomisine göre değerlendirilmesi. Turkish Studies, 12(25), 99-118.

Akyol, H. (2001). İlköğretim okulları 5. sınıf Türkçe kitaplarındaki okuma metinleriyle ilgili soruların analizi. Kuram ve Uygulamada Eğitim Yönetimi, 26, 169-178.

Akyol, H; Yıldırım, K; Ateş, S. \& Çetinkaya, Ç. (2013). Anlamaya yönelik ne tür sorular soruyoruz, Mersin Üniversitesi Ĕ̈itim Fakültesi Dergisi, 9(1), 41-56.

Aslan, C. (2011) Soru sorma becerilerini geliştirmeye dönük öğretim uygulamalarının öğretmen adaylarının soru oluşturma becerilerine etkisi, Ĕgitim ve Bilim, 36(160).

Baysen, E (2006) Öğretmenlerin sınıfta sordukları sorular ile öğrencilerin bu sorulara verdikleri cevapların düzeyleri, Kastamonu Ĕ̌itim Dergisi, 14 (1)

Büyükalan, S. (2007). Soru Sorma Sanatı. Ankara: Nobel Yayıncılık.

Cooper, J. M. (2013). Classroom teaching skills, Wadsworth Cengage Learning, USA 
Çeçen, M. A. ve Kurnaz, H. (2015). Ortaokul Türkçe dersi öğrenci çalışma kitaplarındaki tema değerlendirme soruları üzerine bir araştırma. Karadeniz Sosyal Bilimler Dergisi, 7(02).

Çeliktürk Sezgin, Z. ve Gedikoğlu Özilhan, Y. G. (2019). 1.-8. Sınıf Türkçe ders kitaplarındaki metne dayalı anlama sorularının incelenmesi. Ana Dili Ĕgitimi Dergisi, 7(2), 353-367.

Day, R. R., \& Park, J. (2005). Developing reading comprehension questions. Reading in a Foreign Language, $17(1), 60-73$.

Durukan, E. (2009). 7. sınıf Türkçe ders kitaplarındaki metinleri anlamaya yönelik sorular üzerine taksonomik bir inceleme. Millî Ĕgitim, 181, 84-93.

Erdoğan, T. ve Erdoğan, Ö. (2018). Sınıf öğretmeni adaylarının farklı metin türlerine yönelik hazırladıkları soruların incelenmesi, Turkish Studies, 13 (4), 569-582.

Eyüp, B. (2012). Türkçe öğretmeni adaylarının hazırladığı soruların yeniden yapılandırılan Bloom Taksonomisi’ne göre değerlendirilmesi. Kastamonu Ĕ̆itim Dergisi, 20 (3), 965-982.

Göçer, A. (2016). Lisansüstü eğitim gören Türkçe öğretmenlerinin yazılı sınav sorusu yazabilme yeterlikleri, KAÜ Sosyal Bilimler Enstitüsü Dergisi, 17, 41-57.

Güfta, H. ve Zorbaz, K. Z. (2008). İlköğretim ikinci kademe Türkçe dersi yazılı sınav sorularının düzeyleri üzerine bir değerlendirme. Çukurova Üniversitesi Sosyal Bilimler Enstitü Dergisi, 17, 205-218.

Karakuş, İ. (2002). Türkçe Türk Dili ve Edebiyatı Öğretimi. Ankara: Anıttepe Yayıncılık.

Kocaarslan, M.; Yamaç, A. (2018). Sınıf öğretmenlerinin Türkçe dersi sınavlarında sordukları metne dayalı anlama sorularının incelenmesi, Trakya Üniversitesi Eğitim Fakültesi Dergisi, 8 (2), 431-448.

Miles, M. B. \& Huberman, M. A. (1994). An expanded sourcebook qualitative data analysis. London: Sage.

Sarar Kuzu, T. (2013). Türkçe ders kitaplarındaki metin altı sorularının yenilenmiş Bloom Taksonomisi'ndeki hatırlama ve anlama bilişsel düzeyleri açısından incelenmesi. CÜ Sosyal Bilimler Dergisi, 37 (1).

Ülger, Ü. (2003). İlköğretim 6, 7, 8. Sinıflarda Türkçe Dersi Yazılı Sınav Soruları Üzerine Bir Değerlendirme. Yayımlanmamış yüksek lisans tezi. Gazi Üniversitesi Eğitim Bilimleri Enstitüsü, Ankara.

Ülper, H. ve Yalınkılıç, K. (2010). Son iki Türkçe programına göre hazırlanan Türkçe ders kitaplarındaki metin sonu sorularının nicel ve nitel görünümü. Uluslararası Sosyal Araştırmalar Dergisi. 3 (12), 449-461.

Yıldırım, A. ve Şimşek, H. (2015). Sosyal bilimlerde nitel araştırma yöntemleri. Ankara: Seçkin Yayıncılık. 